\title{
Image Bali as An Ergonomic Island Destination
}

\author{
Ni Made Eka Mahadewi \\ Bali Tourism Institute \\ Sekolah Tinggi Pariwisata Nusa Dua Bali \\ Bali - Indonesia \\ eka.mahadewi@gmail.com
}

\author{
Ni Ketut Dewi Irwanti \\ Udayana University \\ Medicine Faculty - Ergonomic Studies \\ Bali - Indonesia \\ nk_dewi_irwanti@yahoo.com
}

Abstract-For small island economies such as Bali in Indonesia, tourism has been the fastest growing and most important industry accounting for $80 \%$ of their external receipts. These island economies have comparative advantages in tourism because of their small market sizes, rich and unique cultural heritage, marine resources, tropical or sub-tropical climate, hospitality-oriented peoples, serviceintensive nature of tourism. Tourism is a "service" as well as an "export" industry which concerned in service industry. Island tourism, however, heavily depends on tourism and hospitality services based on Bali's human resources.

According to hospitality industry in Bali, the decrease of hotel occupancy creates a quite competitive competition. Thus it requires many efforts to win the competition in this industry. One of them is by encouraging the participation of all parties in providing the best service to achieve quality tourism and to give benefits for society. The efforts which are conducted are expected to increase the competitive ability in facing the changes that are more complex and those efforts aim at providing quality service to meet customer satisfaction.

The major objective of this paper is to identify Bali as an ergonomic island focusing on tourism hospitality with its services based on tourism and ergonomic studies. Bali's tourism industry is now facing a serious turning point because Bali need to improve it service quality to welcome tourists and support Indonesia's target for 20 million foreign tourists.

This paper particularly explained that the service quality based on ergonomic study is the important to improve image Bali as ergonomic tourism destination.

Keywords - Image, Tourist Destination, Ergonomic, Service Quality, Health and Wellness Tourism

\section{INTRODUCTION}

International tourist arrivals grew by $4.4 \%$ in 2015 to reach a total of 1,184 million in 201 . Some 50 million more tourists (overnight visitors) travelled to international destinations around the world last year as compared to 2014. Results from the UNWTO Confidence Index remain largely positive for 2016, though at a slightly lower level as compared to the previous two years. Based on the current trend, UNWTO projects international tourist arrivals to grow by $4 \%$ worldwide in 2016. By region, growth is expected to be stronger in Asia and the Pacific $(+4 \%$ to $+5 \%)$. Asia and the Pacific $(+5 \%)$ recorded 13 million more international tourist arrivals last year to reach 277 million, with uneven results across destinations. Oceania $(+7 \%)$ and South-East Asia $(+5 \%)$ led growth, while South Asia and in North-East Asia recorded an increase of 4\%, (UNWTO, 2016)

Bali, which has been a popular destination for foreigners since the 1930s, is one of the islands that received special attention from the government in order to achieve the government's middle-term target of attracting about 20 million foreign tourists by 2019 in the whole archipelago.

The tourist visitation to Bali increase rapidly every year. Strong domestic market growth since 2008 continues to make Bali one of the leading tourism destinations in ASEAN. With approximately $13 \%$ average annual growth rate in arrivals from 2004 to 2011, the prospects for Bali's tourism and hotel industries are more positive than ever. The new airport expansion promises to support Bali's ability to bring in more tourists. With more than $8 \%$ growth in international arrivals and $22 \%$ in domestic travelers between 2010 and 2011, Bali is showing resilience to the uncertainties in Europe and the US (Howarth, 2012).

Bali Tourism Board statistic on March 2016 recorded the growth of tourist visitation to Bali $15.26 \%$ which increased compared to previuos year that was only $6.25 \%$. By nationality, most foreign tourists came to Bali in March 2016 is tourists from Australia, China, Japan, the UK, and Malaysia with the percentage of each amounting to $23.82 \%, 15.75 \%$, $5.85 \%, 5,21 \%$ and 4.19 . 


\begin{tabular}{|c|c|c|}
\hline \multirow{2}{*}{\multicolumn{3}{|c|}{$\begin{array}{l}\text { FOREIGN TOURISTS ARRIVAL TO BALI } \\
\text { 2008- MARCH } 2016\end{array}$}} \\
\hline & & \\
\hline YEAR & TOTAL & GROWTH (\%) \\
\hline 2008 & $1,968,802$ & \\
\hline 2009 & $2,229,915$ & 11.26 \\
\hline 2010 & $2,493,058$ & 11.80 \\
\hline 2011 & $2,756,579$ & 10.57 \\
\hline 2012 & $2,892,019$ & 4.91 \\
\hline 2013 & $3,278,598$ & 13.30 \\
\hline 2014 & $3,756,618$ & 14.89 \\
\hline 2015 & $4,002,171$ & 6.25 \\
\hline 2016 & $1,000,583$ & 15.26 \\
\hline
\end{tabular}

Source : Bali Tourism Board/GIPI Bali (2016)

\section{Literature REVIEW}

\section{A. Tourism Destination Image}

According to Nadeau, Heslop, O'Reilly and Luk (2008), tourism is a way for people to expose themselves to other countries and to contribute to the images formed about the countries. Given the increasing number of tourism destinations resulting from competition in the global tourism market, one potential strategy is customizing the development of destination brands and creating a unique identity for local tourism (Ekinci \& Hosany, 2006).

Morrison (2013: p.289) put that destination image as one of part the marketing and managing tourism destination. The ment'pictures' of people have in their minds of specific tourism destinations. These image are formed from multiple sources of information. Destination image are difficult to change in the sort term. Destination images are under the control of the tourists and are how they perceive destinations. Morrison put destination image in one chapter as one marketing strategy which is called PIB (Positioning, Image and Branding) approach.

\section{B. The Image of Bali as Tourist Destination}

Based on Bali Hotel and Restaurant Association (2016), there were more than 130,000 hotel rooms available in Bali by the 2016. The growth of tourist visitation is followed by the growth of hotel. This gave impact on decreasing hotel occupancy from average $62 \%$ per year in 2008 - 2013 into $51 \%$ in 2015 .

The decrease of hotel occupancy creates a quite competitive competition in hospitality industry. Thus it requires many efforts to win the competition in this industry. One of them is by encouraging the participation of all parties in providing the best service to achieve quality tourism and to give benefits for society. The efforts which are conducted are expected to increase the competitive ability in facing the changes that are more complex and those efforts aim at providing quality service to meet customer satisfaction (Manuaba, 2015).

There are various factors that influence the efforts to improve customer satisfaction such as existing regulation, government support, infrastructure, tourist as customer, service system, human resources role, society and surrounding environmental condition (Manuaba, 2015). From various components that are present, the role of worker is an important asset and his or her performance is still improvable.

From perspectives of destination image; Bali is well known as a cultural tourist destination. Holloway (2009; p.259) defined that cultural tourism is one of the fastest growing area of tourism.

\section{Health, Wellness and SPA Tourism}

There are three types of tourist activities which are related to after works and relax. They called health tourism, wellness tourism and SPA tourism where the tourists need relax and enjoy. Some people need to enjoy and relax when they are free from works and feel healthy. Tourists who come to destination need a satisfaction, minimize work stress, and increase motivation and productive. It is not fully as medical tourism. It is only as a part of it. Medical tourism can be defined as the process of traveling outside the country of residence for the purpose of receiving medical care. The most common types of procedures that patients pursue during medical tourism trips are elective cosmetic surgery, dentistry, organ transplantation, cardiac surgery and orthopedic surgery. However, a wide variety of services can be obtained through medical tourism, ranging from various essential treatments to different kinds of traditional and alternative treatments (Mestrovic, 2016). According to this definition, Bali need to focus in how create an alternative treatments especially SPA to be a medical product with an ergonomic quality standard for their workers.

Report from ITC explained about current trends in global medical tourism. It draws on the experience of four Asian countries - India, Malaysia, Thailand and the Philippines - to extract lessons and the best practices for another Asian country, Sri Lanka that demonstrates considerable potential in medical and wellness tourism given its traditional knowledge of ayurvedic treatments. It concludes by highlighting the role that international organizations, in particular the International Trade Centre (ITC), can play in helping developing countries grow their domestic capabilities and join the global health tourism industry

Wellness is the optimal state of health of individuals and groups. In 1948 the World Health Organization [WHO] defined health as: "A state of complete physical, mental and social well-being and not merely the absence of disease or infirmity" (Wellness Tourism Worldwide, 2011). The WHO expanded this definition afterwards to include broader issues of wellness and lifestyle management, stating that health involves: "The extent to which an individual or a group is 
able to realize aspirations and satisfy needs, and to change or cope with the environment. Health is a resource for everyday life, not the objective of living; it is a positive concept, emphasizing social and personal resources as well as physical capabilities" (WTW, 2011). This definition is one of the most widely-accepted definitions of health. However, it corresponds more to what is known now as Wellness.

One important element of health tourism is treatment at spa. Spa means health through water or Sanitas Per Aqua, sometimes called 'healing water' (Morrison, 2013: p.214). In Bali, there is Bali Spa and Wellness Association (BSWA). Bali has developed in the past decades into a prominent world spa destination, host to among the best spas in the world that offer unique and sometimes exotic hillside or beachfront settings, with treatments that range from Balinese massages, herbal scrubs using fresh and natural ingredients, hot stone massages, and aromatherapy using locally sourced essential oils.

At the other side, this research focusing on ergonomic site. The word "Ergonomics" comes from two Greek words "ergon," meaning work, and "nomos" meaning "laws." Today, however, the word is used to describe the science of "designing the job to fit the worker, not forcing the worker to fit the job.". Ergonomics is the science of designing the workplace, keeping in minds the capabilities and limitations of the worker. Poor worksite design leads to fatigued, frustrated and hurting workers. This rarely leads to the most productive worker. The goal of ergonomics is to reduce work-related discomfort and musculoskeletal disorders, and increase productivity and job satisfaction by adapting the job to fit the employee, versus adapting the employee to fit the work.

\section{EMPIRICAL RESEARCH}

According to research method, both the type of field research and the nature of the method were qualitative and exploratory. The primary data used were collected through indepth interviews to explore the content found in the real context of the sample (Hair et al.,2011).

Two types of resources persons are from: (i) academic professor on medicine studies (ii) an expert from stakeholders who concern on international tourism. The interviewees were located in Bali.

The instrument used as a basis for personal communication during interviews was a script in the native language of the interviewee. To assess the content of the collected data, the conceptual model and the associated steps of Cooper (1993) and Hair et al. (2011) were used. Thus, after transcribing the interviews and taking notes, the responses were categorized according to the theoretical model being investigated and then analyzed, compared, and explored. The analysis structure for the interpretation of the transcribed text was based on the following steps: (i) relating the theoretical frameworks to their respective concepts in the context of the research theme, (ii) and (ii) citing relevant passages in full, as verbalized by the respondents.

\section{Presentation and analysis of Result}

A model, Figure 1, has been developed to help illustrate the position of ergonomic on tourism system. It depicts the direction of the flow of influence of each factor as either being unidirectional or bidirectional. As such, some factors only influence tourist destination while others both influence and are influenced by tourist destination.

One of the experts interviewed, identified as E1, commented on the image of Bali which is famous with cultural tourist destination:

This type of image needs to be more developed. Bali is not only nature and culture. In my view, the image of Bali can improve to be an ergonomic island destination. The island has been seen as the island of God; the island of paradise; the morning of the world; the island with thousand temples; but now it is not enough. Bali need a new image, and one of them is Bali as an ergonomic island destination.

The implementation of ergonomic studies to tourism studies is on "how people included workers and tourists need to be health, wellness, satisfied and become more productive”.

Workers on their workplace who implemented their ergonomic module feel decreases on workload, fatigue, and muscle complaint and also there were increases on their satisfaction, motivation and productivity of work. At the other side from tourist perspectives, tourists who visit Bali can enjoy their trips by minimizing their work stress through health, wellness and spa activities. This is a 'cause and effect" design product. This combination will be improved Bali to be a new atmosphere of tourists destination.

Another expert interviewed (E2) described his image of Bali:

In my point of view, Bali is a peaceful tourist destination. From Balinese activities can drew Bali to be a cultural tourist destination. But it is not enough that a destination only stand on one image with old fashion. Bali is Bali. Bali with their gorgeous nature and culture, need to promote itself as a new tourist destination with a new image which is can impact and generate tourists to come to Bali. In the future, satisfaction, health and wellness factors are points for tourists when they choose a destination. Standard services with international classification of workers must be fulfilled.

Several references from primary data based on paper research corroborate the examples given by Manuaba (2016) and Dewi (2016) in which the positive image of Bali is epitomized by human factors related to work, workplaces and job design.

Figures 1 show those aspects previously cited regarding the image of $\mathrm{B}$ as an ergonomic island. By implementing the ergonomic quality standard to workers in tourism field, and related to tourists who need health and wellness after their 
work; and the tourists taking their activities in Bali to be a part of medical tourism.

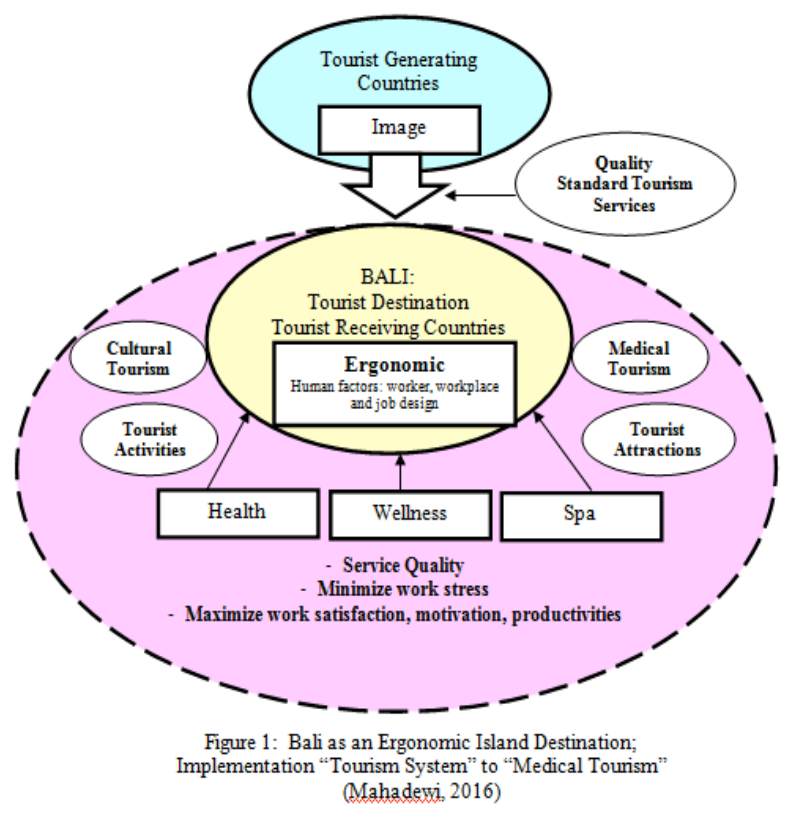

\section{CONCLUDING AND REMARKS}

This article has evaluated the image of Bali as a tourism destination based on the existing literature with additional references from academician on medicine and tourism expert.

Based on that, this investigation found that the image of Bali is still puzzle and need to be improved as an ergonomic island destination. Not all of the tourism stakeholders understood the meaning and the function of ergonomic to tourism sectors. A disparity was found in associations of Bali's image in various contexts from the destination image characteristics. As shown in the literature review and supported by field research, the image for a tourism destination cannot be developed simply through tourism workers with its component; the image is shaped by a broad set of factors or based on a holistic process.

Therefore, it can be concluded from the present study that the image of Bali as an ergonomic island destination is not fixed; rather, it has the potential to evolve and thereby may contribute effectively to the ability of Bali to draw international tourism as well as foreign investment. However, to enable a strategic effort, more studies are needed of specific markets to capture the interest in purchasing Bali products and services due the image of a tourism destination, which is formed by associations with Bali. It is believed that to improve the marketing of the image of Bali, the development of a strategic plan with a communications program aimed at promoting international tourism would be legitimate.

Additionally, by the same token, Manuaba (2015) research findings state that in order to overcome the tourists' feelings of strangeness about a destination, an effort in improving communication and information at the destination site should be arranged. The author also insists that in addition to a careful analysis of the consequences of opting for specific segments, in a holistic planning approach could further help destinations to develop in a more successful and sustainable way by actively managing demand.

\section{Recommendation}

Tourism is a complex phenomenon. Ergonomic oriented internal service can be started to be implemented in hospitality industry. Ergonomic has been proven to reduce workload, musculoskeletal complaint, fatigue, and work stress of the room attendants and also able to increase satisfaction, motivation and work productivity of hotel's room attendants. From tourism perspective, ergonomic is an image tool to Bali as tourist destination.

\section{References}

[1] Bridger, R.S. Introduction to Ergonomics 2nd edition. Taylor \& Francis, Inc. London. 2003.

[2] Chiang, F. F., Birtch, T. A., \& Kwan, H. K. The Moderating Roles Of Job Control And Work-Life Balance Practices On Employee Stress In The Hotel And Catering Industry. International Journal of Hospitality Management, 2010. 29(1), 25-32.

[3] Cooper, C. Hall, MC. Contemporary Tourism, an International Approach, Butterworth-Heinemann, Elsevier Sabre Foundation. Linacre House Jordan Hill, UK. 2008. ISBN 978-756-6350-2.

[4] Cooper, C. Fletcher, J. Gilbert, D. Wanhill. S. Tourism: Principles and Practice. London: Longman. 1993.

[5] Crough, G. I. Perdue, R. R. Timmermans, H. J. P. Uysal, M. 2004. Consumer Psychology of Tourism, Hospitality \& Leisure. Volume 3, UK: Cabi Publishing.

[6] Ekinci, Y., \& Hosany, S. Destination personality: An application of brand personality to tourism destinations. Journal of Travel Research, 2006. 45, 127-139. http://dx.doi.org/10.1177/0047287506291603

[7] Hend M. Hamed. "Wellness Tourism: An Initiative for Comprising Wellness Tourism Vacations within the Corporate Wellness Strategy". Faculty of Tourism and Hotels, Helwan University, Cairo, Egypt. American Journal of Tourism Research. Vol. 4, No. 2, 2015, 52-67. DOI: 10.11634/216837861504643. ISSN 2168-3794 Online. 2015. The Author(s) Published by: World Scholars, http://www.worldscholars.org

[8] Holloway.JC. "The Business of Tourism". Prentice Hall. 2009.

[9] Horwath, HTL. "Hotel, Tourism, Leisure. Special Market Report. Bali Issue-12”. www.howarthhtl.com. 2012

[10] International Trade Centre (ITC). "Medical and Wellness Tourism, Lesson from Asia", Trade Impact for Good 1964-2014.

[11] Izumi, H. Low Back Pain Developing Grows Worse. Department of Ergonomics Institute of Industrial Ecological Sciences, University of Occopational and Environmental Health, Japan. 2008.

[12] Metrovic. " What is Medical Tourism”. http://www.newsmedical.net/health/What-is-Medical-Tourism.aspx . 2016

[13] Morrison A. Marketing and Managing Tourism Destination. Routledge Ltd. 2013.

[14] N. Koncul. "Wellness: A New Mode Of Tourism". Economic Research - Ekonomska istraživanja, Vol. 25 (2012) No. 2 (525-534).

[15] Nadeau, J., Heslop, L., O'Reilly, N., \& Luk, P. Destination in a country image context. Annals of Tourism Research, 35, 84-106. http://dx.doi.org/10.1016/j.annals.2007.06.012

[16] Picard.M. "Cutural Tourism in Bali, Cultural Performance as Tourist Attraction". http://kuveni.de/cultural\%20tourism\%20bali.pdf. 2016

[17] http://www.bali-indonesia.com/magazine/10-best-spa-resorts. 